\title{
Canadian-American Relations in Colonial Printing
}

I CANADAN-AMERCAN RBLATIONS, one 1 fact stands out which helps us to understand each other. It is much more significant than the notoriously undefended frontier. It is the number of people living in Canada with American background, and the number in the United States of $\mathrm{Ca}$ nadian origin and upbringing.

This "mingling of the Canadian and American peoples," as Marcus L. Hansen and J. Bartlet Brebner so aptly term it, ${ }^{1}$ has been characteristic of this continent since the eighteenth century. That century, the latter half a revolutionary epoch in so many ways like our own time, was different from the twentieth in that the Canadian-American frontier was the scene of sporadic conflict. Nevertheless, settlers moved across that frontier in both directions. About the middle of the century the Maritime Provinces changed from nominal to actual British control, and a decade later French Canada became a British colony. Colonials from New England, and from farther south and west, came * north to trade, sometimes to settle, occasionally to fight. The northern settlers found their way down the seaboard, inland waterways, and trails. This mingling of Canadian and American peoples resulted in a mixing of their cultural resources from the earliest days.

A recent attempt to record early $\mathrm{Ca}$ nadian imprints revealed a surprising num-

1 Hansen, Marcus $L_{\text {. }}$ and Brebner, John B. The Mingling of the Canadian and American Peoples (in Relations of Canada and the United States series). New Haven and Toronto, 1940. ber south of the undefended frontier. Printing offices were established in the eastern five provinces of Canada in the latter half of the eighteenth century: in Nova Scotia at Halifax in I75I ; in Quebec at Quebec City in 1764 and Montreal in I775; in New Brunswick at Saint John in I783; in Prince Edward Island at Charlottetown in 1787 ; and in Ontario at $\mathrm{Ne}$ wark (near Niagara) in $\mathbf{I} 793$ and at York, now Toronto, I798. Products of these early presses passed from Nova Scotians and Quebecois to relatives, fellow officials, and professional and business associates, through New England, New York, Pennsylvania, etc. In these older settlements the precarious pioneer era passed earlier, living conditions became stable, society matured and prospered, and cultural institutions developed sooner than in the newer, rather meager, and isolated settlements in the Canadian provinces. So a fair proportion of early Canadian publications which went south survived, while a much greater proportion of the larger number which remained in Canada perished in hands more concerned with the bare necessities for sustaining life.

Of approximately a thousand Canadian imprints recorded for the eighteenth century, perhaps a third of the copies extant are in American libraries. Some of these are relatively recent purchases from $\mathrm{Ca}$ nadian or British dealers. But a large number show evidence of long American custody; for example, the only known copy of one of the earliest Halifax imprints, a 
Price Current of the firm Nathans and Hart, 1752 , is in the Massachusetts Historical Society. A typical case is that of a more common piece, $A$ Sermon Preached at Halifax July $3 d 1770$ at the Ordination of the Rev. Bruin Romcas Comingoe ... by John Seccombe, Halifax, A Henry, I 770. Of eleven copies located so far, five are in Canada and six in the United States -the copy in the John Carter Brown Library having copious manuscript notes written about $\mathbf{1} 772$. Of six fairly good files of the New Brunswick sessions laws (beginning I 786) two are in Canada, one in England, and three in eastern American libraries-and this is typical of Canadian government serials of the period. Most early Canadian newspapers had brief lives, and runs are scattered (excepting the longlived Quebec Gazette with its practically complete file from 1764 in the Public Archives, Ottawa). If we tried to microfilm the succession of Gaxettes produced in Halifax from $\mathrm{I} 752$, we should have to mix runs and issues from the Massachusetts Historical Society, Nova Scotia Legislative Library, New York Public Library, American Antiquarian Society, Nova Scotia Archives, and Dalhousie University. The Catalogue of English and French Books in the Quebec Library, Quebec, 1792, printed in an edition of one hundred, survives in two known copies, of which one is in the Bibliothèque Saint Sulpice, Montreal, the other in the Baker Memorial Library, Dartmouth College-a clean copy, stitched in original marble-paper cover, has its flyleaf inscribed: "Presented to Dartmouth College Library by John Cozens Ogden, a Presbyter of the Episcopal Church, D. College Library, 1792."

The catalogs of the Quebec library, and indeed the collection itself, are excellent research material for one investigating contemporary opinion. This library, the first in Canada, was a subscription library in- stituted by Governor Haldimand, who wrote from Quebec, Mar. 2, I779: "The ignorance of the natives of this colony having been in my apprehension the principal cause of their misbehaviour, and attachment to interests evidently injurious to themselves, I have sought to encourage a subscription for a public Library, which more are come into than would have been first expected. A pretty good sum has already been raised and $I$ hope ... [the library] will tend to promote a more perfect coalition of interests between the old and new [i.e., English and French] subjects of the Crown than has hitherto subsisted."2 The Quebec library developed and continued to function till the midnineteenth century. Its stock was taken over by, and is now housed in, the Literary and Historical Society of Quebec. Two of its early catalogs are described by Aegidius Fauteux in "Les Bibliothèques Canadiennes et Leur Histoire II" in Revue Canadienne 1916, v. 17, p. 199, et seq.

A significant factor in the dissemination of early Canadian publications was the antecedents of their printers. Many of these were of American origin or training. Of the fourteen printing offices opened in Canadian settlements in the eighteenth century, eight were established by printers from the American colonies. Besides these pioneers who founded and maintained the offices, came other printers and journeymen in search of work or adventure, while others arrived as refugees from the American Revolution. A few came earlier, and many later, in the waves of migrants seeking new opportunity or escaping economic pressure in older settlements. Some of these moved back to American towns; others stayed. In either case family and business connections were maintained both ways across the border.

2 Canada Public Archives, Haldimand papers, B66: 
The first was Bartholomew Green, a Boston printer. He was grandson of the Samuel Green who was Stephen Daye's apprentice and successor in the first American press at Cambridge, Mass. When the British government began a systematic settlement in Nova Scotia as a base against the French, Green arrived in Halifax in the fall of $I 75 I$ in the van of a long procession of migrants who made Nova Scotia for a time "New England's Outpost." Green died soon after his arrival, his former Boston partner, John Bushell, came and actually started the printing office. He printed the Halifax Gazette (v. I, no. I, Mar. 25, I 752), proclamations, laws, etc., for the government. Of his nine years' work (he died in January I 76I ) but twentytwo publications are known today. Bushell's son and daughter both learned printing. Characteristic of families at that time, the latter remained in Halifax, while the son served apprenticeship with Daniel Fowle at Portsmouth and then moved to Philadelphia.

After the British conquest of French Canada, another stream of settlers from the older English colonies began to trickle north. Fewer in number than the earlier eastern migrants, they were, in the main, merchants and fur traders. Among them were William Brown ${ }^{4}$ and Thomas Gilmore, printers from Philadelphia. Financed by William Dunlap, in whose shop Brown had learned the trade, they set up the second printing office in Canada, producing the $Q$ uebec Gazette from v. I, no. I, June 2I, I764. Gilmore had little influence in Canadian printing and died in 1773 , but Brown's shop in Quebec became the

Brebner, John Bartlet. New England's Outpost; Acadia before the Conquest of Canada. New York City, Columbia University Press, 1927.

'Parts of Brown's story are told in Canada's First Printer. by Hubert Neilson, a grandnephew, in the Dominion Illustrated, Aug. 18, 1888, and in William Brown (I737-1789) Premier Imprimeur, Journaliste, et Libraire, de Quebec, by F. J. Audet, in Royal Society of Canada, Memoires, 1932 , ser. 3, v. 26, sec. 2, p. 97 I 12. principal printing and bookselling house in the colony. Born in Scotland, he had come to Virginia about $I 752$ at the age of fifteen. He studied briefly at William and Mary College, worked for a banker in Williamsburg, then became an apprentice to William Dunlap. Brown maintained his connections with Philadelphia for a time, paying off the loan from Dunlap, and importing from him Father Abraham's Almanack, Dilworth's Spelling Book, New England Primer, Young Men's Companion, etc., which were the stock in trade of a colonial bookshop. For his unusual French-English public, however, Brown soon began printing simpler and bilingual substitutes for these almanacs, schoolbooks, etc. His ingenious substitute for the almanac, that indispensable adjunct of the colonial household, was his L'Almanac de Cabinet or Calendrier-his "sheet almanac" as he termed it in English. It was a broadside showing the year's calendar, zodiac, moon's phases, religious feast days, and other miscellaneous almanac information. It sold usually at sixpence the copy because, as it was one of the few publications he did not have to set entirely in French and English, its production was relatively cheap. Brown printed three hundred copies in 1765 and complained bitterly at the number left on his hands by unappreciative Quebecois. So he issued none in 1766 , and from 1767 his market was assured. Of the hundreds of copies published each year through the eighteenth century, about two dozen suntanned and flyblown examples survive.

In the long years of the American Revolution Brown's American past receded, for he was King's Printer under the watchful eye of government and the Lieutenant Governor reported: "Our Printer has some penchant for the popular [i.e., American] cause and when he gets a cup too much, which is not seldom, his zeal increases. I have cautioned him two or three times... 
and desire him to lay before me whatever he intends to publish."

The American Revolution retarded the customary travel and trade between the "New and Old Colonies," as they were still called by British officials. But one of the notable American excursions to the north brought another printer to Canada. He was Fleury Mesplet, a protégé of Benjamin Franklin. Franklin was one of the three commissioners who were to follow the revolutionary army to Montreal in the fall of I775. They were to organize among the French Canadians what we now call a fifth column. Mesplet, born in France, had gone to London and thence to Philadelphia in search of work. There, Congress, urging the "New" colony to join the "Old" in their stand for liberty, had Mesplet print its Lettre Addressée aux Habitants de la Province de Québec Cidevant le Canada, de la Part du Congrès Général de I'A mèrique Septentrionale Tenu à Philadelphie ... Fleury Mesplet MDCCLXXIV. The following year he printed Congress' further appeal: Lettre Addressée aux Habitants Opprimés de la Province de Québec de la Part du Congrès Général de l'Amèrique Septentrionale Tenu à Philadelphie [Fleury Mesplet, I 775].

Mesplet apparently made a trip to Montreal in 1775 . The town had never had a printing press. Its Catholic institutions, cut off from France, were ill-supplied with devotional and schoolbooks, and its French-speaking society very remote from William Brown's press a couple of days down the river in Quebec. It seemed a good prospect for a French printer and especially for a French printer with American backing. Congress granted him two hundred dollars for expenses and in the spring of I 776 Mesplet moved his printing office to Montreal, then occupied by the Americans. The latter, however, withdrew very soon, even the commissioners being con- vinced that the "habitants opprimés" would not join the revolution; but Mesplet, in some financial straits, remained. He began printing devotional books, schoolbooks, a French almanac, and a newspaper, Gazette du Commerce et Littéraire pour la Ville et District de Montréal, v. I, no. I, June 3, I778. He had a troubled career beset by suspicious authority and pressing creditors. ${ }^{5}$ It is interesting to note that after the revolution Mesplet petitioned Congress ${ }^{6}$ in I 783 and again in 1784 , begging relief for losses suffered by his move to Montreal. Another copy of the 1784 petition was presented Mar. I I, I 785, with Mesplet's claim for $\$ 9189$. This was $\$ 330$ for "extra expenses" and $\$ 8859$ for other ". . . damage sustained in the sale of books and for debts contracted in the maintenance of himself, workmen, and family, whilst the said Mesplet was on account of his attachment to the cause of America confined in Jail." It was recommended that he be paid $\$ 426.45$ for transportation expenses to Montreal and that his other claims be submitted to the "wisdom and benevolence of Congress."

Except for this contact with Congress Mesplet seems to have had little connection with Americans after he settled in Montreal. He served an almost exclusively French and Catholic community. The books advertised for sale in his shop were limited to his own publications. Even well after the revolution, when he could publish freely and was in fact producing the bilingual Montreal Gazette, there is no evidence of his friendly exchange with printers across the border. Few of his French publications are located today in

- See McLachlan, R. W., "Fleury Mesplet, the First Printer at Montreal," in Royal Society of Canada, Transactions, I906, ser. 2, v. I2, p. 197-309, and Fauteux Aegidius, in "Fleury Mesplet, une Etude sur les Commencements de l'Imprimerie dans la Ville de Montreal" in Bibliographical Society of America, Montreal" in Bibliographical Society of America,
Papers, 1934, v. 28, pt. 2, p. 163-93. Papers, 1934, v. 28, pt. 2, p. 163-93.
6 His petition was reproduced by Douglas C. Mc. Murtrie in $A$ Memorial Printed by Fleury Mesplet. Chicago, Ludlow, I 929. 
American collections, but the situation is different with respect to his productions not in French. The only known copies of his two memorials to Congress are in the $\mathrm{Li}$ brary of Congress. He published two Mohawk primers, of which four of the five known copies are in American libraries. But unlike that of most early Canadian printers, Mesplet's work survives mostly in long-established institutions in his own province. His publications, almanacs, devotional works, and even the political pieces, were produced for the local French market. And the French of Canada traditionally had a different cultural and social background and limited intercourse with American settlers.

The great shifting of population occasioned by the American Revolution brought a number of pro-British printers to Canada. The first of these were Mills and Hicks, who had been publishing the Massachusetts Gazette in Boston. When the city was evacuated in March 1776 they came to Halifax with the British Army. We know of only one Halifax production by them, and it was a curious contretemps. It contained the text of the Declaration of Independence, apparently, and an Act of Rhode Island renouncing allegiance to the king. It was published on July I I, I 776, with the title Extracts from the Boston and New Hampshire Newspapers. The printer, summoned before the lieutenant-governorin-council, explained that the notes showing the heinous nature of this document had been omitted by mistake. All copies were ordered to be collected and destroyed, and this was done so effectively that by July I 3 a military officer in Halifax was unable to get one to send to London, "altho' [he wrote] I have offered to give a Dollar apiece." This was the only contemporary edition of the Declaration of Independence printed in Canada. Mills and Hicks moved on to England, then back to New York while it was occupied by the British. There in 1778 they resumed publication of their almanac, the British-American Register ... with British Army Lists and an Almanack. This had been sold in Halifax for some years by a protégé of the governor. At the end of the revolution Mills and Hicks were back in Halifax. Nathaniel Mills remained there, but John Hicks returned to settle in Massachusetts.

Mills and Hicks typified the experience of many American printers set adrift by the revolution. James and Alexander Robertson went to Shelburne, N. S., Canada, with the crowd of loyalists who tried to make a city on the ocean-swept coast of the peninsula. They opened a printing office, resumed publication of their newspaper, the Royal American Gazette, and then as the new settlement petered out James moved on to Charlottetown. There he opened the first printing office in Prince Edward Island, printed a few more numbers of his newspaper and some laws, but in 1789 left the island for parts unknown. His press was continued with a meager output by young William A. Rind, till Rind returned to Virginia in 1798 with a wife from a Loyalist family on the island. James Humphreys, who had printed the Philadelphia Ledger, also settled for a time in Shelburne. He issued the Nova-Scotia Packet for a couple of years, sat in the provincial assembly, then moved back to Philadelphia in 1797. Humphreys kept in touch with Loyalist colleagues in Nova Scotia, advertised in their newspapers, and received their publications.

Thomas and James Swords were associated with Humphreys for a time in Shelburne. They received land grants as Loyalist settlers, but by 1790 they were back in New York in the printing business.

Lewis and Ryan (William Lewis of New York and John Ryan of Newport, R.I.) were part of the great Loyalist migration 
which pioneered the province of New Brunswick. Arriving at the mouth of the St. John River in $I 783$, they set up a press and issued the first number of the Royal St. John's Gazette, Dec. I8, I783, before the townsite on the edge of the wilderness was surveyed. Young Ryan, who had turned twenty-two years in October I 783 , carried on the printing office when, in the spring of $\mathrm{I} 786$, Lewis left the settlement after a couple years' struggle and a stiff fine for libel. Ryan developed a respectable business and trained his sons to be printers. Then he moved on, in 1807 , to open the first printing office in Newfoundland.

Ryan's father-in-law, the printer John Mott, and his family, also came to the St. John River settlement with the Loyalist migration. But, Mrs. Mott declaring she would "never live in such a God-forsaken place," they returned to New York. After the yellow fever epidemic of 1798 , however, the Motts moved back to St. John. By this time the son, Jacob, was trained as a printer. The Ryans and the Motts printed in half a dozen places on both sides of the boundary for many years, visiting back and forth and working in each others' shops.

The Sowers were another example of the same process. Christopher Sower III, of the third generation of a family of able printers of Germantown, $\mathrm{Pa}$., settled in St. John, N.B., Canada, after the revolution. $\mathrm{He}$ was King's Printer in the province 1 785-99, and his official publications as a whole are the finest productions in early Canadian printing. Christopher's son, Brook Watson, was sent back to Philadelphia to train in his uncle Samuel Sower's shop. And Christopher was in Baltimore arranging to set up a type foundry with his brother, when he died in 1799 . Practically all of Sower's publications were official and are located today in public collections, American and Canadian almost equally.
While there are thus many early Canadian imprints in American custody, it is doubtful if there is a corresponding number of American productions of that period in Canadian hands. A systematic search of Canadian libraries might unearth interesting items, like a broadside in Acadia University Library at Wolfville, N.S. This was evidently issued in Boston I75?, as witness: "Advertisement: All Gentlemen Voluntiers that have a mind to serve $\mathrm{His}$ Majesty King George the Second in an independent Company of rangers for the Service and Defence of Nova Scotia, under command of Benoni Danks Esq. may repair to the sign of the St. George on Boston Neck." Circumstances, however, which mitigated against the preservation of native works in the pioneer period, were probably effective also with imported publications.

Undoubtedly American publications, pamphlets, and newspapers came into $\mathrm{Ca}$ nadian towns in the portmanteaux and saddlebags of travelers. We hear of them only incidentally, as in the case of the Boston and New Hampshire News Papers, brought into Halifax by Judge Hutchinson of Massachusetts in July I 776, from which Mills and Hicks printed the Declaration of Independence as noted above. Many such publications probably circulated quietly, wore out, and helped light a fire or stuff a drafty crack. Canadian printers were dependent upon American sources of news for a large part of the year. Not only American but European news came through Boston to Halifax and St. John, and through New York to Quebec, Montreal, and Upper Canada. News of Nelson's victory at the Battle of the Nile on Aug. I, I798, was published in York (now Toronto) on Jan. 12, I799, in an Upper Canada Gazette Extraordinary. The Gazette's issue was made up from the columns of the New York Mercantile Advertiser of Nov. 30, I 798, which reprinted dispatches 
from the London Gazette of Oct. 5-6, I 798.

Canadian printers occasionally advertised and distributed publications of their American confreres. John Dickinson's Letters from an American Farmer was sold in Halifax in 1768 and probably also in Quebec. Lewis and Ryan of St. John sold the Hartford 1783 edition of the Narrative of the Life of William Beadle of Wethersfield, Connecticutt, containing Particulars of the Horrid Massacre of Himself and His Family. The Boston 1772 edition of Wellins Calcott's Candid Disquisition of the Principles and Practice of ... Free and Accepted Masons was being read in Halifax the same year. The same work was advertised by Lewis and Ryan, almost as soon as they opened their shop in St. John. Masonic publications were sold by William Brown of Quebec, himself a good Mason. But, except in the 1760 's, these were probably imported from England.

Religious pamphlets deriving from a popular preacher or sect with adherents on both sides of the frontier circulated on both sides. Henry Alline, a native of Rhode Island and a fiery New Light evangelist, published his sermons in Nova Scotia, while his Life and Journal and his Hymns and Spiritual Songs, were published in New England after his death. Thomas Wood's Sermon Occasioned by the Death of Mrs. Abigail Belcher, Consort of Jonathan Belcher, Chief Justice of Nova-Scotia, was printed in Halifax, $177 \mathrm{I}$, and in Boston, I772. Jonathan was the son of Governor Belcher of Massachusetts.

Loyalist writers brought their American works, and Loyalist readers brought their American reading interests with them to
Canada. A Particular Account of $M r$. Thomas Say of Philadelphia While in a Trance for Eight Hours, Giving a Strange Revelation of What He Both Saw and Heard . . . To which is Added: A Remarkable Vision by the Rev'd. Isaac Watt, went through several. American editions from I 774 onwards. About the time of Say's death it was advertised continuously in St. John, I 796-97, by John Ryan, who may even have issued his own edition.

William Cobbett's works had considerable sale in Canada in the I 790's. In fact his sympathizers there are said to have compensated him for losses from the libel suit of Dr. Benjamin Rush. His Democratic Principles... Sixteenth Edition, was issued in Quebec in 1799.

The Canadian printing trade was sufficiently precarious in those early days. And we may be sure that a Canadian edition of an American work is evidence of a local market which knew the book by reputation at least.

These random notes on early American publications in Canada, gathered incidentally in connection with another project, suggest an interesting field for research. The latter part of the eighteenth century saw the beginning of a unique relationship between the peoples of these two countries and also between their printing establishments as these developed-a relationship so close that very many families and many publishing houses have branches and connections on both sides of the line. And many books like The Mingling of the Canadian and American Peoples by M. L. Hansen and J. B. Brebner are issued with American-Canadian imprints. 